\title{
Effect of Brea Gum on the characteristics of wheat bread at different storage times
}

\author{
Estela Patricia LÓPEZ ${ }^{1 \star}$, Gabriela Teresa PÉREZ ${ }^{2}$, \\ Patricia Liliana Jiménez de ERRAMOUSPE ${ }^{3}$, Carlos Mario CUEVAS ${ }^{4}$
}

\begin{abstract}
The effect of Brea Gum (BG) addition on a basic bread formulation is described. The aim of the study was to investigate the effect of BG on the characteristics of wheat bread in terms of changes in moisture, texture, retrogradation of amylopectin, and microstructure. Bread quality was assessed by the physical parameters (volume, specific volume index, width/height ratio, crumb moisture, color, and hardness) and crumb grain structure (total cell number, total cell area, average size of cells, and number of cells per unit area). The effect of BG on the characteristics of the crumb during 24, 48, and 72 hours of storage was determined according to changes in moisture, hardness, and amylopectin retrogradation. Furthermore, the microstructure of the crumb was analyzed by scanning electron microscopy (SEM). The results show the ability of BG to retain moisture in the bread crumb, which was expressed by the lower hardness of the bread crumbs with the addition of the hydrocolloid at 48 and 72 hours of storage. This effect was also evident in the microstructure.
\end{abstract}

Keywords: Brea Gum; bread quality; crumb texture; microstructure.

\section{Introduction}

Bread is a widely consumed product, particularly wheat bread. Bread quality loss takes place due to staling that begins just when loaves are taken out from the oven (BÁRCENAS; ROSELL, 2005). Staling involves several physical and chemical phenomena, recristallyzation of the amylose, and amylopectin (HUG-ITEN; ESCHER; CONDE-PETIT, 2003; ZOBEL; KULP, 1996), loss and redistribution of water (CZUCHAJOWSKA; POMERANZ, 1989; HOSENEY; ZELEZNAK; LAI, 1986), and protein-starch interaction (CHAMP; FAISANT, 1992; ELIASSON; LARSSON, 1993; EVERY et al., 1998) are the most important ones.

During storage the most evident changes are related to moisture content loss and crumb hardening (DAVIDOU et al., 1996).

Hydrocolloids are widely used as additives in the food industry because they are useful for modifying the rheology and texture of aqueous suspensions (DZIEZAK, 1991) due to their high water retention capacity (LEE et al., 2002). In baked goods, hydrocolloids have been used for retarding staling and for improving the quality of fresh products (BÁRCENAS; ROSELL, 2005). In fact, guar, xanthan, arabic, carrageenans, alginates, pectin and cellulose derivatives have been widely used (GUARDA et al., 2004; ROSELL; ROJAS; BENEDITO DE BARBER, 2001; SHARADANANT; KHAN, 2003).

The Brea gum (BG) is a hydrocolloid obtained as phloematic exudate of Cercidium praecox harms. The two most common species found in Argentine are C. praecox (Brea tree) and
Cercidium australe (Brea arbustus). The genus Cercidium belongs to Leguminosae family. With their extensive root system, Brea trees can be found in semi-arid regions of Argentine. Brea trees grow scattered in the wild, and the gum from these untended trees is collected manually by the native people. The exudate gum is obtained from superficial incisions made in the branches and tree trunks. After some weeks, the partially dry gum exudates are manually collected. The exudate is purified by a simple process of solution and subsequent dried and ground into a fine powder. The production and composition of BG is complex and varies somewhat depending on the geographical origin, climatic conditions and the age of the trees. BG has an amber colour and a semi-liquid consistency with a faintly sweet flavour. It is highly soluble in water. Solutions are homogeneous and present acid character $(\mathrm{pH}=4)$. This hydrocolloid contains residues of L-arabinose, D-xylose, D-glucuronic acid and 4-Omethyl- D -glucuronic acid at the approximate molar ratios of 1.7:6, 3:1 and 9:0.9 respectively (CEREZO; STACEY; WEBBER, 1969; DE PINTO et al., 1993), associated with small amounts of protein (approximately 8\%) which contribute to their emulsifying properties. The major structural features of BG appear to be a $\beta$ - $(1 \rightarrow 4)$-linked d-xylan backbone [possibly containing some $(1 \rightarrow 2)$-linkages] that is 2 -substituted by short branch chains containing residues of $\mathrm{d}$-xylose (and l-arabinose) and d-glucuronic acid, in which both types of residue may be terminal (CEREZO; STACEY; WEBBER, 1969). BG shares structural and chemical similarities with other plant gums

\section{Received $7 / 18 / 2013$}

Accepted 10/4/2013 (006171)

${ }^{1}$ Food Laboratory, Faculty of Engineering, Research Institute of Chemical Industry - INIQui, National University of Salta - UNSa, Bolivia Avenue, 5150, CP 4400, Salta, Argentina, e-mail:epl_81@yahoo.com.ar

${ }^{2}$ School of Agricultural Sciences, National University of Cordoba, Consejo Nacional de Investigaciones Científicas y Técnicas - CONICET, Valparaíso Avenue, s/n, CP 5000, Córdoba, Argentina

${ }^{3}$ Food Laboratory, Faculty of Engineering, Research Council, National University of Salta - CIUNSa, Bolivia Avenue, 5150, CP 4400, Salta, Argentina

${ }^{4}$ Faculty of Engineering, Research Council, National University of Salta - CIUNSa, Bolivia Avenue, 5150, CP 4400, Salta, Argentina

${ }^{*}$ Corresponding author 
widely used in the food industry such as Arabic gum (DE PINTO et al., 1993). Hence, BG could be a suitable candidate for incorporation as stabilising, emulsifying, and thickening additive in food formulation. Brea gum has been traditionally used as a "woodland candy" by countryside people since preColombian times without producing harmful consequences. Von Müller et al. (2009) reported a toxicological evaluation of BG in mice. Their results suggest that feeding BG at levels up to $5 \%$ to mice do not exert any toxicological effects, supporting its potential use as a food additive for human consumption.

The aim of this study was to analyze the possible effect of BG as an improver of bread crumbs, acting as an anti aging. For that purpose the texture, microstructure, moisture and retrogradation of the amylopectin in bread crumb in the presence of BG were studied.

\section{Materials and methods}

\subsection{Materials}

Commercial wheat flour (10\% moisture content, $11.79 \%$ protein and $0.71 \%$ ash), compressed yeast and other ingredients were purchased from local markets. BG was provided by indigenous communities from Chaco Salteño.

\subsection{Methods}

\section{Purification of $B G$}

The native BG was purified at the laboratory; firstly it was solubilized in water at room temperature and it was then successively filtered. Once clean, BG was dried in an oven at low temperature and was milled to a particle size of 80 mesh $(0,173$ $\mathrm{mm}$ - ASTM). Since BG has high solubility in water $(28.3 \%$ at $25^{\circ} \mathrm{C}$ ), the fine powder was solubilized in the water required for kneading [approximately $60 \%$ water $\mathrm{w} / \mathrm{w}$ of flour, measured by farinographic analysis (data not shown)] to ensure a good distribution of the hydrocolloid throughout the dough.

\section{Breadmaking process}

To test the effect of BG the following proportions were used: $0 \%$ (control bread) $0.5 \%$ and $1 \%$ (test bread) $\mathrm{w} / \mathrm{w}$ flour based. The dough was prepared using the following proportions of ingredients based on $100 \mathrm{~g}$ of flour: dried yeast $1 \%$, salt $1.6 \%$, and water $55.7 \%$ for the control bread; $57.5 \%$ for breads with $0.5 \%$ of BG addition; and $58.7 \%$ for breads with $1 \%$ of BG addition.

The ingredients were mixed and kneaded in a commercial bread maker machine (ATMA easy cook). The dough was fermented at $27^{\circ} \mathrm{C}$ for 95 minutes and kneaded ( 25 minutes); baking was performed at $150{ }^{\circ} \mathrm{C}$ for 60 minutes. Finally, the bread was cooled to room temperature for 120 minutes. For the study of aging, the loaves were placed unpacked into a special camera and stored at $25^{\circ} \mathrm{C} \pm 2{ }^{\circ} \mathrm{C}$ with a $75-80 \%$ relative humidity for 24,48 , and 72 hours. Three loaves were prepared and stored for analyzes at each storage time.

\section{Technological evaluation of fresh bread}

Physicochemical characteristics of fresh breads

Physicochemical characteristics of fresh breads including weight, volume (rapeseed displacement) (V), specific volume index (specific volume of control loaves were taken as $100 \%$, and the specific volume of the samples with BG referred to this value of the control bread) (SVI). The width/height ratio $(\mathrm{W} / \mathrm{H})$ of the central slice, moisture content (AMERICAN..., 1995, method 925.10), and hardness of fresh crumb (see section 2.2.4.2.) were assessed.

Fresh bread crumb color

The color of the crumb was determined with a ColeParmer colorimeter using the CIELAB parameters $\left(\mathrm{L}^{\star}, \mathrm{a}^{\star}, \mathrm{b}^{\star}\right)$. The visual sensations that are sent to the brain create the three dimensions of colour judgment response that is often referred to as three-dimensional colour space. In the CIE Lab system, these dimensions are expressed as: $L^{\star}$ related to lightness varying from black (zero) to white (100), and the other two are related to chromaticity: $\mathrm{a}^{\star}$ from green $\left(-\mathrm{a}^{\star}\right)$ to red $\left(+\mathrm{a}^{\star}\right)$ and $\mathrm{b}^{\star}$ from blue $\left(-b^{\star}\right)$ to yellow $\left(+b^{*}\right)$. The CIE (Commission Internationale de l'Eclairage) $\mathrm{L}^{*}, \mathrm{a}^{*}$, and $\mathrm{b}^{*}$ colour characteristics were determined using the ColorTec, PCM colorimeter (Accuracy Microsensor Inc., Pittsford, USA) equipped with light source D65 and an observation angle of $10^{\circ}$. Three measurements were averaged for each sample.

Image acquisition and analysis of the fresh crumb

The analysis of the crumb structure was performed by scanning and digitizing the crumb image. Images were taken from the centre of the each bread slice and were captured using an Epson scanner (Epson Stylus CX5900). Crumb cells were analysed by the ImageJ software programme (Version 1,44p, Wayne Resband, National Institute of Health, USA). This software allows the selection of the central image of the crumb and determines the area expressed in $\mathrm{mm}^{2}$ (I). It then converts to 8-bit images to obtain a black and white threshold, allowing a clear distinction between black cells. This allows calculation of the average cell size $(\mathrm{mm})$, the number of cells present in the selected area (II), and the total area occupied by cells (\% area fraction). To calculate the amount of cells per $\mathrm{cm}^{2}$, the value (I) is converted into $\mathrm{cm}^{2}$, and the ratio of the parameters (I) and (II) is then calculated.

Thus, the total area cells (\%) (TAC), the average size of the cells $(\mathrm{mm})$ (ASC), and the number of cells per unit area $\left(\mathrm{n}^{\circ} \mathrm{C} /\right.$ $\mathrm{cm}^{2}$ ) were calculated. Three replicates for each sample were carried out.

\section{Bread crumb staling}

The aging of bread was determined by variation in the moisture, hardness, and retrogradation of amylopectin of the crumbs (control sample and with the addition of BG) during storage at 2 (fresh bread), 24, 48, and 72 hours. 
Crumb moisture content

Moisture content was determined in fresh and stored samples, according to the AACC official method (method 925.10) (AMERICAN..., 1995). Three replicates for each sample were carried out.

Crumb hardness

Crumb hardness was measured in a QTS 25 texturometer (Brookfield). A $2.5 \mathrm{~cm}$ thick slice was compressed with a $38.1 \mathrm{~mm}$ acrylic probe up to $40 \%$ deformation, at $120 \mathrm{~mm} / \mathrm{min}$ speed and 60 seconds of hold time. Analyzes were performed six times for each sample.

Retrogradation of amylopectin

A differential scanning calorimeter (DSC- Q200, TA Instruments, USA) was used to determine the amylopectin retrogradation. Crumb samples (control and with the addition of BG) from different times of storage were weighed (60 mg \pm 5 ) inside aluminum pans of $100 \mu \mathrm{L}$ (T0 pans, Switzerland). Empty pans were used as reference. After sealed, the pans were heated from 27 to $120^{\circ} \mathrm{C}$ at $10{ }^{\circ} \mathrm{C} / \mathrm{min}$ speed. The parameters measured were: the onset temperature $\left(\mathrm{T}_{0}\right)$, peak temperature $\left(\mathrm{T}_{\mathrm{p}}\right)$, final temperature $\left(\mathrm{T}_{\mathrm{f}}\right)$, and amylopectin retrogradation $\left(\Delta\right.$ Hret); straight lines were drawn between the $\mathrm{T}_{0}$ and $\mathrm{T}_{\mathrm{f}}$, and the enthalpy associated to the amylopectin retrogradation was calculated as the area enclosed by the straight lines and endotherm curves; it was expressed in joules per gram $(\mathrm{J} / \mathrm{g})$ of dry sample (BÁRCENAS; ROSELL, 2005). Four replicates for each sample were carried out.

Scanning electron microscopy (SEM) of bread crumbs

A Jeol scanning electron microscope (JSM 6480 LV, Tokyo, Japan) was used, with an acceleration voltage between 0.2 and $30 \mathrm{Kv}$, including sensors for secondary and backscattered electrons, working with high and low vacuum. The bread samples were initially treated with glutaraldehyde and ethylic alcohol $\left(98^{\circ}\right)$ and dried up to a critical point and finally metalized with gold.

\section{Statistical analysis}

The data obtained were subjected to analysis of variance (ANOVA) and Tukey's test using the software program of Statistical Package for the Social Sciences (SPSS, 17.0) in order to assess significant differences among samples. Differences were considered significant when $p<0.05$.

\section{Results and discussion}

\subsection{Effect of BG addition on the quality of fresh crumbs}

The quality parameters of the loaves with BG is described in Table 1.

Although the addition of $1 \%$ BG appears to increase the $\mathrm{V}$ and SVI of the pieces of bread, this effect was not statistically significant $(p<0.05)$. It can be seen that the specific volume and the SVI of the samples with BG were similar to the control. This effect was positive since the addition of BG, in any of the proportions studied, does not affect the volume, unlike other hydrocolloids used in baking that impair the volume of breads, such as alginate (ROSELL; ROJAS; BENEDITO DE BARBER, 2001). These differences can be due to be different origins of the hydrocolloids.

The shape of the loaf slices was not affected by the different percentages of BG added.

The moisture content of the fresh samples containing BG were significantly $(\mathrm{p}<0.05)$ higher than that of the control, which was expected due to an increase in the amount of water necessary for the formation of the dough, (up to optimum consistency of 500 Brabender units). This indicates that the water absorption of the dough with BG was higher. This effect was due to the water retention ability of this polymer resulting from the hydrophilic nature of most gums (GUARDA et al., 2004; CHRISTIANSON et al., 1981; COLLAR; ARMERO; MARTÍNEZ, 1999; GURKIN, 2002; TWILLMAN; WHITE, 1988). Perhaps, this behavior can demonstrate that during cooking, the hydrocolloid forms a network that could act as a barrier to the diffusion of gases, which in turn would reduce vapor losses resulting in higher moisture content of crumb bread

Table 1. Influence of the addition of GB on the quality parameters of fresh bread.

\begin{tabular}{cccc}
\hline & Control & $0.5 \%$ & $1 \%$ \\
\hline V $\left(\mathrm{cm}^{3}\right)$ & $221 \pm 0.12^{\mathrm{a}}$ & $226 \pm 0.27^{\mathrm{a}}$ & $219 \pm 0.51^{\mathrm{a}}$ \\
Specific Volume $\left(\mathrm{cm}^{3} / \mathrm{g}\right)$ & $2.26 \pm 0.05^{\mathrm{a}}$ & $2.23 \pm 0.12^{\mathrm{a}}$ & $2.36 \pm 0.02^{\mathrm{a}}$ \\
SVI (\%) & $100^{\mathrm{a}}$ & $98.94 \pm 5.12^{\mathrm{a}}$ & $104.60 \pm 0.95^{\mathrm{a}}$ \\
W/H & $1.09 \pm 0.06^{\mathrm{b}}$ & $1.10 \pm 0.04^{\mathrm{b}}$ & $1.13 \pm 0.01^{\mathrm{a}}$ \\
Crumb moisture (g\%) & $44.60 \pm 0.17^{\mathrm{a}}$ & $45.34 \pm 0.15^{\mathrm{b}}$ & $45.21 \pm 0.20^{\mathrm{b}}$ \\
Crumb Hardness (g) & $186.33 \pm 9.43^{\mathrm{a}}$ & $217.67 \pm 12.5^{\mathrm{b}}$ & $232.33 \pm 3.95^{\mathrm{b}}$ \\
Area fraction (\%) & $30.55 \pm 1.99^{\mathrm{a}}$ & $30.00 \pm 2.40^{\mathrm{a}}$ & $32.05 \pm 0.07^{\mathrm{a}}$ \\
ASC(mm) & $3.84 \pm 0.03^{\mathrm{a}}$ & $3.17 \pm 0.60^{\mathrm{a}}$ & $5.67 \pm 0.11^{\mathrm{b}}$ \\
$\mathrm{N}^{\circ} \mathrm{C} / \mathrm{cm}^{2}$ & $7.97 \pm 0.42^{\mathrm{b}}$ & $9.46 \pm 1.18^{\mathrm{b}}$ & $5.66 \pm 0.10^{\mathrm{a}}$ \\
\hline
\end{tabular}

Means \pm standard deviation $(n=3)$. Means in the same row with different letters are significantly different ( $<<0.05)$. V: volume; SVI: specific volume index; W/H: width/height ratio; ASC: average size of the cells; ${ }^{\circ} \mathrm{C} / \mathrm{cm}^{2}$ : number of cells per unit area. 
(BELL, 1990). Similar behavior was reported by Bárcenas and Rosell (2005) in breads with added HPMC.

The addition of BG increased the hardness of the bread crumb which could be a consequence of the thickening effect on the crumb walls surrounding air spaces, as proposed by Guarda et al. (2004) and Rosell, Rojas and Benedito de Barber (2001) for xanthan gum. These unusual characteristics compared with those presented by other similar molecular weight polysaccharides are related to the branched and more compact molecular structure in BG (BERTUZZI; SLAVUTSKY; ARMADA, 2012).

Crumb cellular structure is an important quality criterion used in commercial baking and research laboratories to judge bread quality along with taste, crumb color, and crumb physical texture (KAMMAN, 1970; PYLER, 1988; ZAYAS, 1993).

As for the crumb structure, it was observed that in the bread with further addition of BG there were fewer cells, but they were larger; thus, the total area covered by cells was higher in the crumb supplemented with $1 \%$ of BG. In the crumb supplemented with $0.5 \%$ of BG there were no significant differences from the crumb control bread, suggesting that the minimal addition of hydrocolloid does not alter the quality of the crumb, while the maximum addition seems to favor the formation of larger cells, which would lead to a heterogeneous crumb structure. BG.

Figure 1 shows the color profile of crumbs with and without

The $L^{\star}$ parameter showed no significant differences between the control and the crumb supplemented with $0.5 \%$ of $B G$, while it showed a significant decrease in the crumb with $1 \%$ BG. Parameters $a^{\star}$ and $b^{\star}$ showed a significant increase in the crumb with the maximum level of added hydrocolloid. This was expected since BG has a clear tendency to yellow $\left(\mathrm{L}^{*}: 78.01 ; \mathrm{a}^{*}\right.$ : $\left.2.63 ; b^{*}: 20.49\right)$. With regard to the red and yellow dyes, there was an increase proportional to the amount of BG added to the formulation. The crumb supplemented with $1 \%$ of BG was creamy yellow and opaque.

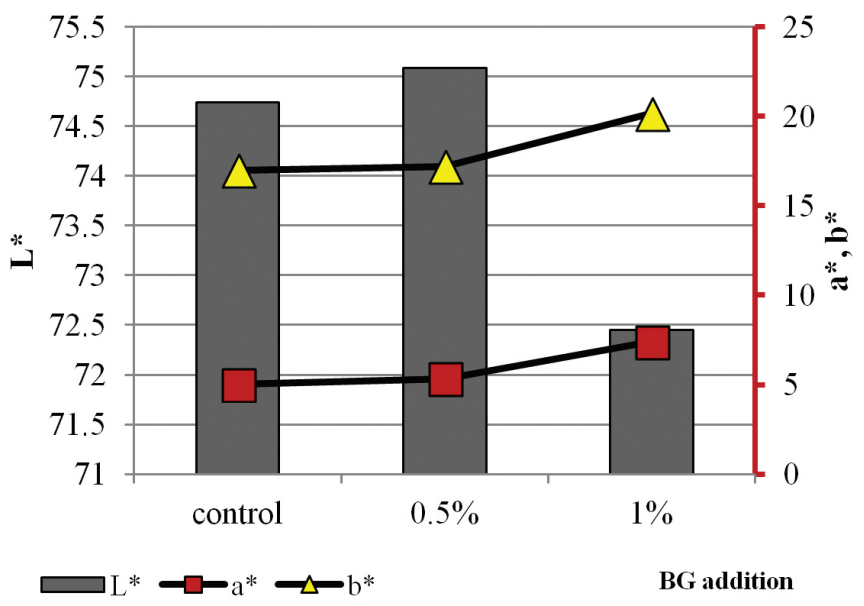

Figure 1. Color profile of bread crumbs with different additions of BG.

\subsection{Effect of BG on the crumb staling during storage}

In Figure 2, it can be seen that the moisture content of the crumbs during the three days of storage at $25^{\circ} \mathrm{C}$.

The bread crumbs with BG were more humid than the control sample at 48 and 72 hours of storage. The difference was significant. Since there were no differences between the moisture content of the breads with hydrocolloid, it appears that the minimum addition of $\mathrm{BG}$ promotes moisture retention in the bread crumb.

Similar results were reported by Guarda et al. (2004), who studied the effect of some hydrocolloids such as $\kappa$-carrageenan, xanthan, HPMC, and alginate and found that all of those hydrocolloids would reduce moisture loss from the crumb, even when a small percentage of them was added to the formulation. Davidou et al. (1996) reported a similar result in the locust bean gum; it can reduce the loss of moisture and dehydration rate during storage, in comparison to that the control sample.

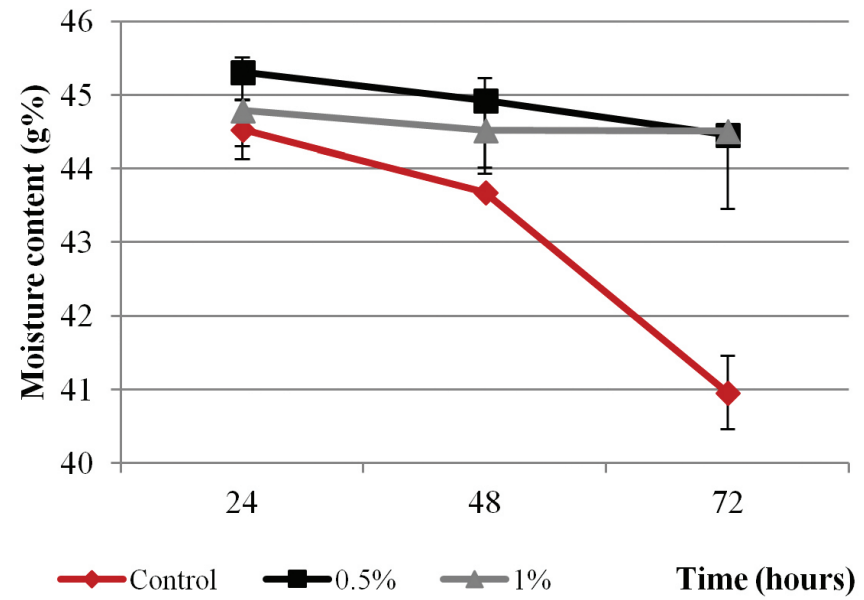

Figure 2. Moisture variation in white bread crumbs with different levels of addition of BG, stored for 72 hours.

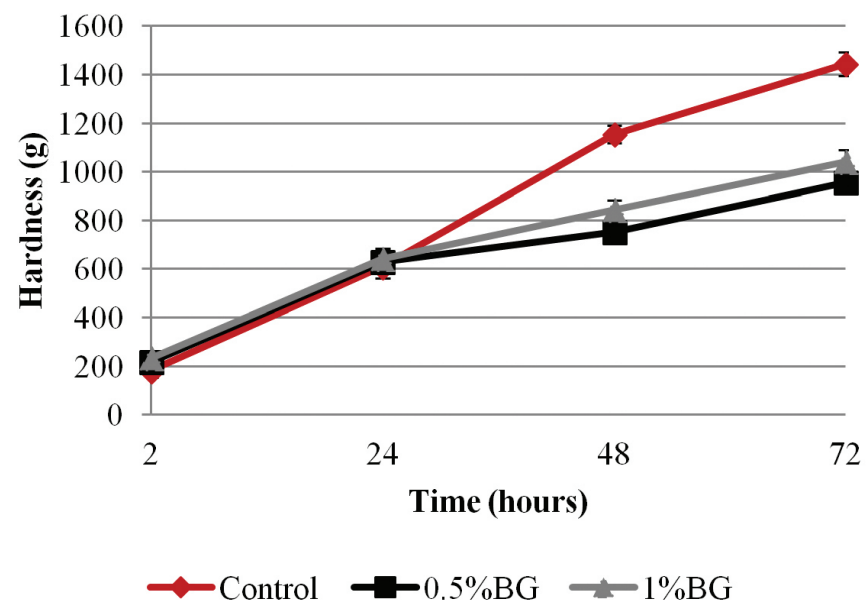

Figure 3. Effect of BG on the hardness variation of the crumb at different storage times. 
These observations seem to indicate that, regardless of their origin, the gums can help reduce the loss of moisture from the crumb. This is attributable to increased water retention and better water distribution which affects the crumb hardness (ARMERO; COLLAR, 1996; EIDAM et al., 1995).

Figure 3 shows the hardness increase of the crumb during the bread storage at $25^{\circ} \mathrm{C}$. The crumb hardness increased during storage with or without BG. However, after 24 hours, there was no difference in the hardness of the crumbs in the presence or absence of BG although breads containing BG had significantly lower values of crumb hardness at 48 and 72 hours of storage resulting in a softer crumb than the control. The lower crumb hardness obtained in the samples containing BG could be related to the high moisture content of these crumbs at 48 and 72 hours of storage since the inverse relationship between hardness and moisture content has been widely reported (HUGITEN; ESCHER; CONDE-PETIT, 2003; SHARADANANT; KHAN, 2003; FIK; SUROWKA, 2002; LEUNG; MAGNUSON; BRUINSMA, 1983; RIBOTTA; LEÓN; AÑÓN, 2003). Similar results have been found by other authors who have studied other gums such as HPMC, alginate, and $\kappa$-carrageenaner. Sharadanant and Khan (2003) found that the addition of hydrocolloids such as carboxymethylcellulose, arabic and locust bean gum to the bread formulation led to a lower hardening rate during the storage of bread crumbs. Opposite effects with xanthan were also reported (BÁRCENAS; ROSELL, 2005; GUARDA et al., 2004; ARMERO; COLLAR, 1998).

The hydrocolloid mechanism has not yet, been completely understood, and many authors have proposed some hypothesis. It seems that the effect of gums results from two opposite phenomena: firstly, due to an increase in the rigidity as a consequence of the decrease in the swelling of the starch granules and the amylose lixiviation; secondly, due to a weakening effect on the starch structure caused by inhibition of the amylase chain association (BILIADERIS et al., 1997). Other authors (ARMERO; COLLAR, 1996; EIDAM et al., 1995) proposed that hydrocolloids have a weakening effect on the starch structure that promotes better water distribution and retention and a decrease in the crumb resistance. $\mathrm{He}$ and Hoseney (1990) proposed that the decrease in moisture content favors the rapid formation of cross-links between starch molecules and proteins, yielding a faster hardening of the bread and, as a consequence, if the hydrocolloids can act in favor of the retention of water in the crumb structure, there will be less hardening. The power of the effect will depend on the specific hydrocolloid (GUARDA et al., 2004).

Texture results showed that the lowest BG concentration $(0.5 \% \mathrm{w} / \mathrm{w}$ flour basis) is sufficient to change crumb hardness, while no further modification was obtained by increasing the hydrocolloid concentration.

The results regarding the retrogradation of amylopectin are shown in Figure 4.

The values for $\Delta$ Hret of the control bread were similar to those reported by Le Bail et al. (2009).

It is important to note that in the first 24 hours of storage, the crumb supplemented with $1 \%$ BG had a significantly higher

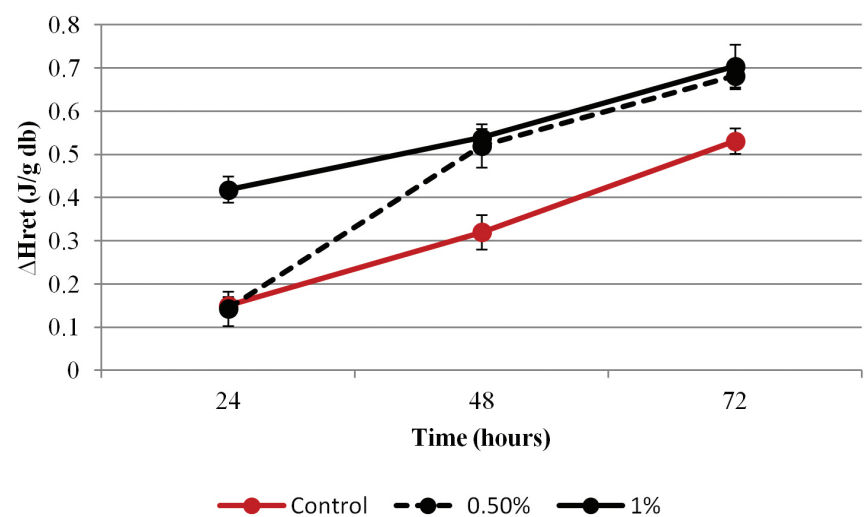

Figure 4. Evolution of the melting enthalpy of amylopectine (DHret) during storage.

$\Delta$ Hret than that of the crumb of the control sample and that supplemented with $0.5 \%$ of BG. This would suggest a significant decrease in the amount of water available for starch in the crumb with the addition of $1 \%$ of BG (DAVIDOU et al., 1996; MIURA; NISHIMURA; KATSUKA, 1992; ROULET, 1988; PISESOOKBUNTERNG; D'APPOLONIA, 1983).

After 48 hours of storage, the $\Delta$ Hret of the two types of crumbs with BG did not differ, suggesting a higher rate of retrogradation than that of the control samples (Figure 4). At 72 hours, both crumbs added with GB had higher $\Delta$ Hret than that of the control, and the difference was significant.

Many authors demonstrated that retrogradation was not the only factor responsible for the firmness of the bread crumb but rather, hardness would be the result of macromolecular interactions causing entanglements (COLWELL, 1969; RAO; NUSSINOVITCH; CHINACHOTTI, 1992; ROGERS et al., 1988; MCLVER et al., 1968).

With respect to the moisture content, the results of the thermograms do not agree with what is proposed in the literature as generally accepted. Specifically, when there is higher water content, there is less retrogradation in the sample (BÂRCENAS; ROSELL, 2005; DAVIDOU et al., 1996; LE-BAIL et al., 2009; PRIMO MARTÍN et al., 2007; LEÓN; DURÁN; BENEDITO DE BARBER, 1997).

This behavior could be explained by a competition for water between the hydrocolloid and starch. Part of the water of the system would be retained in the structure of the BG, which would explain the results in the moisture content and hardness of the crumb. The starch in the crumbs supplemented with $B G$, is provided with a certain amount of water that is less than that of the control crumb, but enough to act as a plasticizer in the reorganization of the amylopectin molecule. Rogers et al. (1988) concluded that starch retrogradation and hardening of the crumb are uncorrelated with each other in a certain range of moisture contents and, according to several authors, the moisture content close to $40 \%$ would highly favor starch retrogardation and bread firming (DAVIDOU et al., 1996; HE; HOSENEY, 1990; ROGERS et al., 1988; ZELEZNAK; HOSENEY, 1986). 
The lower hardness of the bread crumbs with the addition of BG would be due to higher water content in the crumb structure. The higher moisture content would be due to the water trapped by the hydrocolloid in the crumb structure. In the present study, the hardness of the crumb was not correlated with retrogradation of amylopectin.
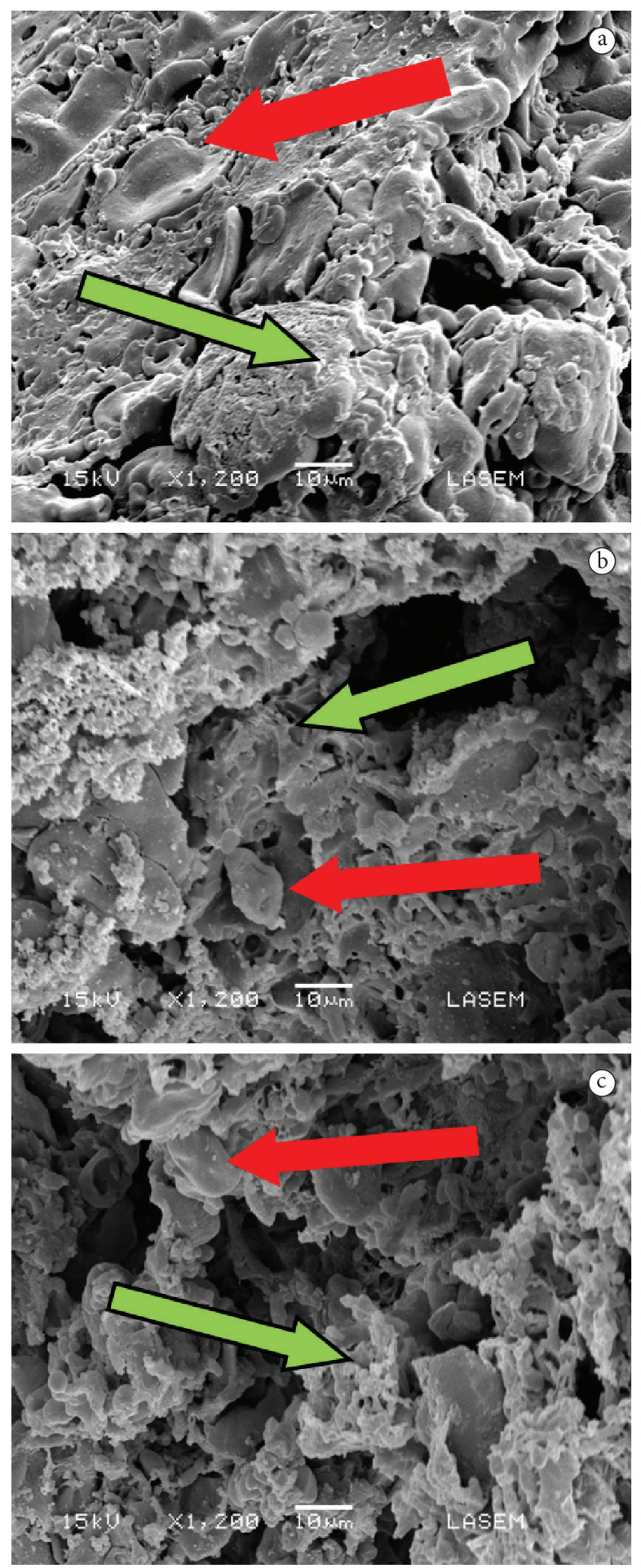

Figure 5. Effect of BG on the microstructure of fresh crumbs and at 72 hours of storage. a and d: control crumbs (a: fresh, d: $72 \mathrm{hs}$ of storage), b and e: crumb with $0.5 \%$ BG (b: fresh, e: stored), c and f: crumb 1\% GB (c:fresh, f: stored). White arrows show rigid areas observed in the samples; red arrows indicate the presence of clearly visible starch granules; and green arrows show the network structure containing the granules.
It can be concluded from this experiment, in agreement with Davidou et al. (1996), that bread firming during storage cannot be explained by starch retrogradation alone or by the moisture content. The organization of polymers within the amorphous region, the repartition of water between the amorphous and crystalline regions of bread crumb, or the
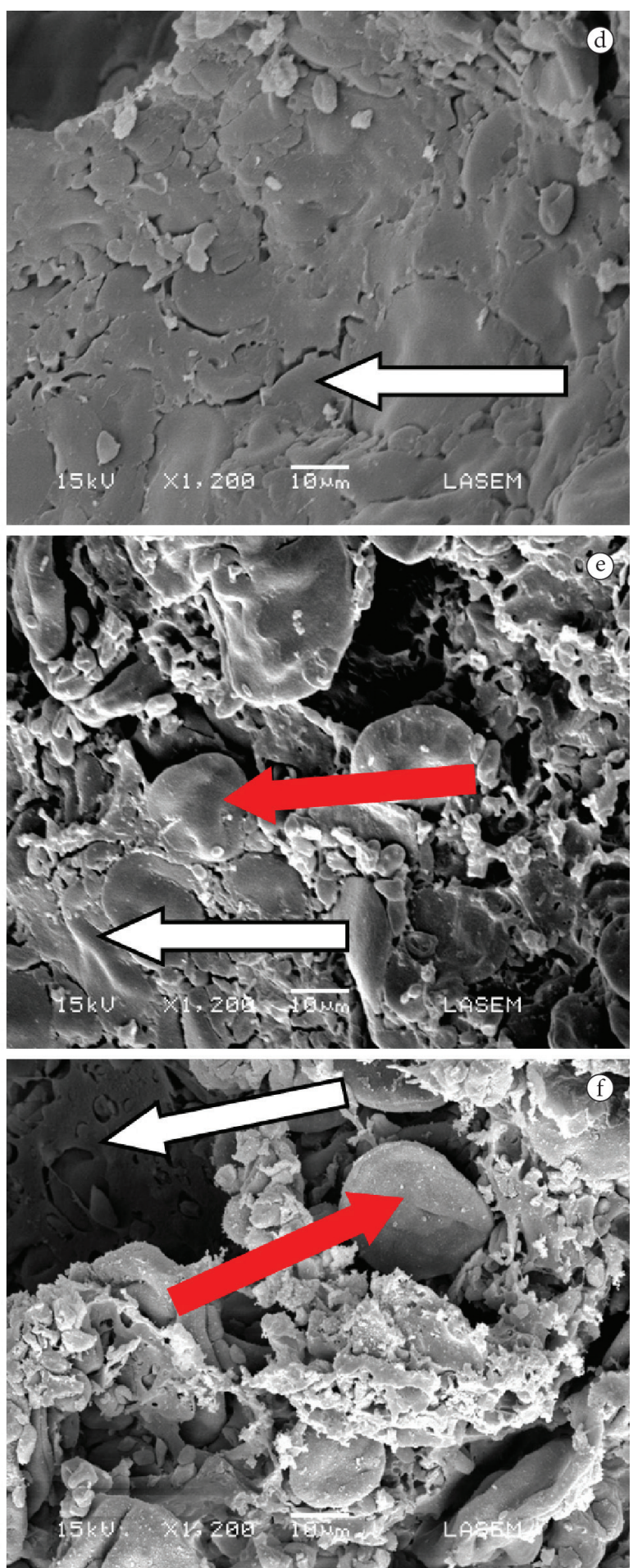
macroscopic structure, i.e the porosity of the crumb, may play an important role.

\subsection{Effect of BG on the crumb microstructure}

Figure 5 shows the SEM micrographs of fresh and stored crumbs (after 72 hours) of the control bread and the breads containing BG.

The fresh crumbs are shown in Figures 5a, 5b, and 5c. They clearly distinguish the components of the flour (starch granules and protein bodies) inserted in a dense network (gluten). After 72 hours of storage, the control sample (Figure $5 \mathrm{~d}$ ) showed a rigid structure in which the components of the flour could not be distinguished. It is a rigid, cracked structure without air gaps. This finding in the microstructure may explain the greater increase in the hardness of bread control crumb at 72 hours of storage. Furthermore, the greater hardness may be due to greater loss of moisture from the crumb control since there is more rigidity in the structure when the polymers are more effectively cross-linked (MULLER, 1969).

Figures $5 \mathrm{e}$ and $5 \mathrm{f}$ show the crumbs of bread with BG added and stored for 72 hours. Compared with the control sample, the crumbs added with BG still reveal the flour components (starch granules and gluten network) although it slightly distinguishes an area with a rigid structure (Figure 5 - white arrows).

These notable differences in the microstructure of the crumbs stored may explain changes in hardness up to 72 hours of storage, showing that the addition of BG decreases the hardness of the crumb. This behavior can be explained by the fact that BG would allow water to remain in the system, reducing the hardening rate.

This corroborates the findings of various authors that the loss of moisture will evidently contribute to a change in the properties of the cell walls (HUTCHINSON; MANTLE; SMITH, 1989), which would be manifest as a firming of the crumb (PIAZZA; MASI, 1995). Changes in the structure of the bread crumbs in relation to hardening have been little studied (ZOBEL; KULP, 1996), but studies on image analysis (BÁRCENAS; ROSELL, 2006) indicate significant structural changes resulting from moisture loss of the crumb (SCANLON; ZGHAL, 2001). This study of the microstructure was a very useful resource to argue graphically the decrease in the hardness of the crumbs with added BG.

\section{Conclusion}

The addition of BG reduced the hardening of the crumb of the white bread, particularly at 48 hours of storage. This improvement may be due to the higher moisture content of the crumbs with BG. The higher moisture content would also explain the differences found in the microstructure at 72 hours of storage. It should be noted that the same effect is observed regardless of the amount of BG added. However, the presence of the hydrocolloid seems to favor the retrogradation of amylopectin, which probably would be due to a competition for water between starch and BG. The bread firming during storage cannot be explained by starch retrogradation alone or by the moisture content. The organization of polymers within the amorphous region or the repartition of water between the amorphous and crystalline regions may play an important role.

\section{Acknowledgements}

The authors wish to thank Professor Mark Shaw for his valuable help revising the language. They also acknowledge Dr. Pablo Corregidor for his collaboration with the new DSC analysis.

\section{References}

AMERICAN ASSOCIATION OF CEREAL CHEMISTS. Approved Methods of the AACC. 6th. ed. St Paul: American Association of Cereal Chemists, 1995.

ARMERO, E.; COLLAR, C. Antistaling additive effects on fresh wheat bread quality. Food Science and Technology International, v. 2, n. 5, p. 323-333, 1996. http://dx.doi.org/10.1177/108201329600200506

ARMERO, E.; COLLAR, C. Crumb firming kinetics of wheat breads with anti-staling additives. Journal of Cereal Science, v. 28, n. 2, p. 165-174, 1998. http://dx.doi.org/10.1006/jcrs.1998.0190

BÁRCENAS, M. E.; ROSELL, C. M. Different approach for improving the quality and extending the shelf-life of the partially baked bread: low temperatures and hydrocolloid addition. Food Chemistry, v. 100, p. 1594-1601, 2005. http://dx.doi.org/10.1016/j. foodchem.2005.12.043

BÁRCENAS, M. E.; ROSELL, C. M. Different approach for improving the quality and extending the shelf-life of the partially baked bread: low temperatures and HPMC addition. Journal of Food Engineering, v. 72, n. 1, p. 92-99, 2006. http://dx.doi.org/10.1016/j. jfoodeng.2004.11.027

BELL, D. A. Methylcellulose as a structure enhancer in bread baking. Cereal Foods World, v. 35, n. 10, p. 1001-1006, 1990.

BERTUZZI, M. A.; SLAVUTSKY, A. M.; ARMADA, M. Physicochemical characterization of the hydrocolloid from Brea tree (Cercidium praecox). International Journal of Food Science and Technology, v. 47, p. 776-782, 2012. http://dx.doi.org/10.1111/j.13652621.2011.02907.x

BILIADERIS, C. G. et al. Effect of hydrocolloids on gelatinization and structure formation in concentrated waxy maize and wheat starch gels. Starch/Staerke, v. 49, n. 7-8, p. 278-283, 1997.

CEREZO, A. S.; STACEY, M.; WEBBER, J. M. Some structural studies of Brea Gum (an exudate from Cercidium australe Jonhst). Carbohydrate research, v. 9, n. 4, p. 505-517, 1969. http://dx.doi. org/10.1016/S0008-6215(00)80035-X

CHAMP, M.; FAISANT, N. Technology and Quality Nutritonnelle Starches. In: BERNARD, A.; CARLIER, H. (Ed.). Nutritional Aspects of Food Technology Influence. Paris: Cahiers de l'ENSBANA, 1992. cap. 1, p. 1-23.

CHRISTIANSON, D. D. et al. Gelatinization of wheat starch as modified by xanthan gum, guar gum, and cellulose gum. Cereal Chemistry, v. 58, n. 6, p. 513-517, 1981.

COLLAR, C.; ARMERO, E.; MARTÍNEZ, J. C. Optimization of hydrocolloid addition to improve wheat dough functionality: a response surface methodology study. Food Hydrocolloids, v. 13, n. 6, p. 467-475, 1999. http://dx.doi.org/10.1016/S0268005X(99)00030-2

COLWELL, K. H. et al. Effect of storage temperature on the ageing of concentrated wheat starch gels. Journal of the Science of Food and Agriculture, v. 20, n. 9, p. 560-563, 1969. http://dx.doi.org/10.1002/ jsfa.2740200909

CZUCHAJOWSKA, Z.; POMERANZ, Y. Differential scanning calorimetry, water activity, and moisture content in crumb center and near-crust zones of bread during storage. Cereal Chemistry, v. 66, n. 4 , p. p. $305-309,1989$. 
DAVIDOU, S. et al. A contribution to the study of staling of white bread: effect of water and hydrocolloid. Food Hydrocolloids, v. 10 , n. 4 , p. $375-383,1996$. http://dx.doi.org/10.1016/S0268005X(96)80016-6

DE PINTO, G. et al. Composition of Cercidium praecox gum exudates. Biochemical Systematics and Ecology, v. 21, n. 2, p. 297-300, 1993. http://dx.doi.org/10.1016/0305-1978(93)90048-V

DZIEZAK, J. D. A focus on gums. Food Technology, v. 45, n. 3, p. 115-132, 1991.

EIDAM, D. et al. Formation of maize starch gels selectively regulated by the addition of hydrocolloids. Starch, v. 47, n. 10, p. 378-384, 1995. http://dx.doi.org/10.1002/star.19950471003

ELIASSON, A. C.; LARSSON, K. Cereals in Breadmaking: A molecular colloid approach. New York: Marcel Dekker, 1993. 376 P.

EVERY, D. et al. Newberry MP. Staling in starch bread: the effect of gluten additions on specific loaf volume and firming rate. Starch, v. 50, n. 10, p. 443-446, 1998. http://dx.doi.org/10.1002/(SICI)1521379X(199810)50:10<443::AID-STAR443>3.0.CO;2-3

FIK, M.; SUROWKA, K. Effect of prebaking and frozen storage on the sensory quality and instrumental texture of bread. Journal of the Science of Food and Agriculture, v. 82, n. 11, p. 1268-1275, 2002. http://dx.doi.org/10.1002/jsfa.1176

GUARDA, A. et al. Different hydrocolloids as bread improvers and antistaling agents. Food Hydrocolloids, v. 18, n. 2, p. 241-247 2004. http://dx.doi.org/10.1016/S0268-005X(03)00080-8

GURKIN, S. Hydrocolloids-Ingredients that add flexibility to tortilla processing. Cereal Foods World, v. 47, n. 2, p. 41-43, 2002.

HE, H.; HOSENEY, R. C. Changes in bread firmness and moisture during long-term storage. Cereal Chemistry, v. 67, n. 6, p. 603605, 1990.

HOSENEY, R. C.; ZELEZNAK, K. J.; LAI, C. S. Wheat gluten: a glassy polymer. Cereal Chemistry, v. 63, p. 285-286, 1986.

HUG-ITEN, S.; ESCHER, F.; CONDE-PETIT, B. Staling of bread: role of amylose and amylopectin and influence of starch-degrading enzymes. Cereal Chemistry, v. 80, n. 6, p. 654-661, 2003. http:// dx.doi.org/10.1094/CCHEM.2003.80.6.654

HUTCHINSON, R. J.; MANTLE, S. A.; SMITH, A. C. The effect of moisture content on the mechanical properties of extruded food foams. Journal of Materials Science, v. 24, n. 9, p. 3249-3253, 1989. http://dx.doi.org/10.1007/BF01139048

KAMMAN, P. W. Factors affecting the grain and texture of white bread. Bakers Digest, v. 44, n. 2, p. 34-38, 1970.

LE-BAIL, A. et al. Impact of the baking kinetics on staling rate and and mechanical properties of bread crumb and degassed bread crumb. Journal of Cereal Science, v. 50, n. 2, p. 235-240, 2009. http://dx.doi. org/10.1016/j.jcs.2009.05.008

LEE, M. H. et al. Freeze-thaw stabilization of sweet potato starch gel by polysaccharide gums. Food Hydrocolloids, v. 16, n. 4, p. 345-352, 2002. http://dx.doi.org/10.1016/S0268-005X(01)00107-2

LEÓN, A.; DURÁN, E.; BENEDITO DE BARBER, C. A new approach to study starch changes occurring in the dough-baking process and during bread storage. Zeitschrift für Lebensmittel Untersuchung und Forschung, v. 204, n. 4, p. 116-120, 1997.

LEUNG, H. K.; MAGNUSON, J. A.; BRUINSMA, BL. Water binding of wheat flour doughs and breads as studied by deuteron relaxation. Journal of Food Science, v. 48, n. 1, p. 95-99, 1983. http://dx.doi. org/10.1111/j.1365-2621.1983.tb14797.x

MCLVER, R. G. et al. Kinetic study of the retrogradation of gelatinized starch. Journal of the Science of Food and Agriculture, v. 19, n. 10, p. 560-563, 1968. http://dx.doi.org/10.1002/jsfa.2740191003
MIURA, M.; NISHIMURA, A.; KATSUKA, K. Influence of addition of polyol and food emulsifiers on the retrogradation rate of starch. Food Structure, v. 11, n. 3, p. 225-236, 1992.

MULLER, H. G. Application of the statistical theory of rubber elasticity to gluten and dough. Cereal Chemistry, v. 46, n. 5, p. 443-446, 1969.

PIAZZA, L.; MASI, P. Moisture redistribution throughout the bread loaf during staling and its effect on mechanical properties. Cereal Chemistry, v. 72, n. 3, p. 320-325, 1995.

PISESOOKBUNTERNG, W.; D’APPOLONIA, B. L. Bread staling studies I. Effect of surfactants on moisture migration from crumb to crust and firmness values of bread crumb. Cereal Chemistry, v. 60 , n. 4 , p. $298-300,1983$.

PRIMO MARTÍN, C. et al. Crystallinity changes in wheat starch during the bread-making process: starch crystallinity in the bread crust. Journal of Cereal Science, v. 45, n. 2, p. 219-226, 2007. http://dx.doi. org/10.1016/j.jcs.2006.08.009

PYLER, E. J. Wheat and wheat flour. In: BAKING science and technology, volume II. 3rd ed. Merriam Kansas: Sosland Publishing, 1988. cap. 7, p. 850- 910.

RAO, P. A.; NUSSINOVITCH, A.; CHINACHOTTI, P. Effects of selected surfactants on amylopectin recrystallization and on recoverability of bread crumb during storage. Cereal Chemistry, v. 69, n. 6, p. 613-618, 1992.

RIBOTTA, P.; LEÓN, AE.; AÑÓN, C. Effect of freezing and frozen storage on the gelatinization and retrogradation of amylopectin in dough baked in a differential scanning calorimeter. Food Research International, v. 36, n. 4, p. 357-363 2003. http://dx.doi.org/10.1016/ S0963-9969(02)00227-2

ROGERS, D. E. et al. Effect of native lipids, shortening, and bread moisture on bread firming. Cereal Chemistry, 1988 Sep, v. 65, n. 5, p. 398-401.

ROSELL, C. M.; ROJAS, J. A.; BENEDITO DE BARBER, C. Influence of hydrocolloids on dough rheology and bread quality. Food Hydrocolloids, v. 15, n. 1, p. 75-81, 2001. http://dx.doi.org/10.1016/ S0268-005X(00)00054-0

ROULET, P. et al. A comparative study of the retrogradation kinetics of gelatinized wheat starch in gel and powder from using X-ray, differential scanning calorimetry and dimanic mechanical analisys. Food Hydrocolloids, v. 2, n. 5, p. 381-396, 1988. http://dx.doi. org/10.1016/S0268-005X(88)80003-1

SCANLON, M. G.; ZGHAL, M. C. Bread properties and crumb structure. Food Research International, v. 34, n. 10, p. 841-864, 2001. http://dx.doi.org/10.1016/S0963-9969(01)00109-0

SHARADANANT, R.; KHAN, K. Effect of hydrophilic gums on the quality of frozen dough: II. Bread characteristics. Cereal Chemistry, v. 80, n. 6, p. 773-780, 2003. http://dx.doi.org/10.1094/ CCHEM.2003.80.6.773

TWILLMAN, T. J.; WHITE, P. J. Influence of monoglycerides on the textural shelf life and dough rheology of corn tortillas. Cereal Chemistry, v. 65, n. 3, p. 253-257, 1988.

VON MÜLLER, A. R. et al. Subchronic toxicological evaluation of brea gum (Parkinsonia praecox) as a food additive in BALB / c mice. Drug and Chemical Toxicology, v. 32, n. 4, p. 307-311, 2009. PMid:19793021. http://dx.doi.org/10.1080/01480540902976903

ZAYAS, I. Y. Digital image texture analysis for bread crumb grain evaluation. Cereal Foods World, v. 38, n. 10, p. 760-766, 1993.

ZOBEL, H.; KULP, K. Baked goods freshness: The staling mechanism. New York: Marcel Dekker, 1996. cap. 1, p. 1-64.

ZELEZNAK, K. J.; HOSENEY, R. C. The role of water in the retrogradation of wheat starch gels and bread crumb. Cereal Chemistry, v. 63, n. 5, p. 407-411, 1986. 